\title{
Variability in climatology and agricultural production in China in association with the East Asian summer monsoon and El Niño Southern Oscillation
}

\author{
Fulu Tao ${ }^{1,2, *}$, Masayuki Yokozawa ${ }^{2}$, Zhao Zhang ${ }^{3}$, Yousay Hayashi ${ }^{3}$, \\ Hartmut Grassl ${ }^{4}$, Congbin $\mathrm{Fu}^{5}$ \\ ${ }^{1}$ Chinese Academy of Agricultural Sciences, Institute of Agricultural Environment and Sustainable Development, \\ Beijing 100081, China \\ ${ }^{2}$ National Institute for Agro-Environmental Sciences, 3-1-3 Kannondai, Tsukuba, Ibaraki 305-8604, Japan \\ ${ }^{3}$ Institute of Geoscience, University of Tsukuba, Tsukuba, Ibaraki 305-8571, Japan \\ ${ }^{4}$ Max Planck Institute for Meteorology, Department for Climate Processes, Bundesstrasse 55, 20146 Hamburg, Germany \\ ${ }^{5}$ START Regional Center for Temperate East Asia, Institute of Atmospheric Physics, Chinese Academy of Sciences, \\ Beijing 100029, China
}

\begin{abstract}
The East Asian monsoon (EAM) and the El Niño Southern Oscillation (ENSO) determine climate variability over much of East Asia, affecting vulnerable grain markets and food security in China. In this study, we investigated the variability of climate and of agricultural production in China in association with the East Asian summer monsoon (EASM) and ENSO. Data from China showed that a strong EASM decreased fall temperature in Gansu and Sichuan Provinces in western China, as well as winter temperature in Heilongjiang Province in NE China and in Shandong and Anhui Provinces in eastern China. Summer rainfall in Hunan Province in southern China increased in weak EASM years. Summer temperature increased in Heilongjiang in NE China and Gansu Province in NW China during the La Niña phase. Summer rainfall decreased in Gansu Province in NW China during the El Niño phase. Among staple crops in China (rice, wheat, maize), maize production was very vulnerable to a strong EASM and El Niño phase. In Henan Province in central China, seasonal climate variability associated with EASM and ENSO resulted in about 14.4 and 15.6\%, respectively, of maize yield variability. Maize yield at the national scale decreased significantly by $5.2 \%$ during the El Niño phase. Cropland area affected and damaged by floods in Hunan Province in southern China increased significantly by 11.3 and $8.5 \%$, respectively, in weak monsoon years. During the La Niña phase, total crop planting area increased significantly in Shandong, Henan and Anhui Provinces in central China, and in Heilongjiang Province in NE China; however, it decreased significantly in Sichuan Province in SW China. The large variability in seasonal climate and agricultural production in association with EASM and ENSO warrant applying EASM and ENSO information to agricultural and food market management.
\end{abstract}

KEY WORDS: Agriculture · China · Climate variability · ENSO · Monsoon · Food security · Warning system

\section{INTRODUCTION}

The climate in China is highly variable, due to the influence of various factors such as the strength of the East Asian monsoon (EAM), ENSO, snow cover on the
Tibetan Plateau, and the presence of a subtropical high pressure system in the western Pacific Ocean (Huang \& Zhou 2002). Among these factors, the influence of the EAM is especially strong (Tao \& Chen 1987). Large precipitation variability is a major feature of the 
EAM climate. During the winter half of the year (October-March), the climate is mainly cold and dry, with cold spells and strong winds as the major extreme climate events. During the summer period, a rain belt moves gradually from the south to the north, and the climate in eastern China becomes hot and humid. The high rate of variation in the monsoon climate strongly affects the spatial and temporal variability of Asian ecosystems (Fu \& Wen 2001).

Although ENSO occurs within the tropical Pacific region, its effects are felt around much of the planet, so that it accounts for a substantial portion of the observed inter-annual variability in temperatures and precipitation (Hansen et al. 1999). ENSO influences the spatial patterns of the East Asian Summer Monsoon (EASM), and of drought and floods in China (Fu \& Teng 1988, Huang \& Wu 1989, Zhang et al. 1999, Huang \& Zhou 2002).

Meteorological disaster is an important limiting factor for stable food production, and thus for social and economic development in China (Li et al. 1999, Hayashi 2001). Since 1949, natural disasters have affected an average $3.1 \times 10^{7}$ ha of agricultural surface every year (drought: $62 \%$; flood: $24 \%$; hail: $8 \%$; frost: $6 \%$; see Li et al. 1999). A total population of 200 million people has been affected over the past $50 \mathrm{yr}$, and huge economic losses have been recorded. Mean variability of annual food production is $5.1 \%$, and was up to $17.6 \%$ between 1951 and 1980 .

Extensive studies have been conducted on regional rainfall variability due to the influence of ENSO (e.g. Fu \& Teng 1988, Huang \& Wu 1989, Kripalani \& Kulkarni 1997, Gong \& Wang 1999, Kane 1999, Zhang et al. 1999, Nicholson \& Selato 2000, Verschuren et al. 2000, Xu et al. 2004) and EAM (e.g. Tao \& Chen 1987,

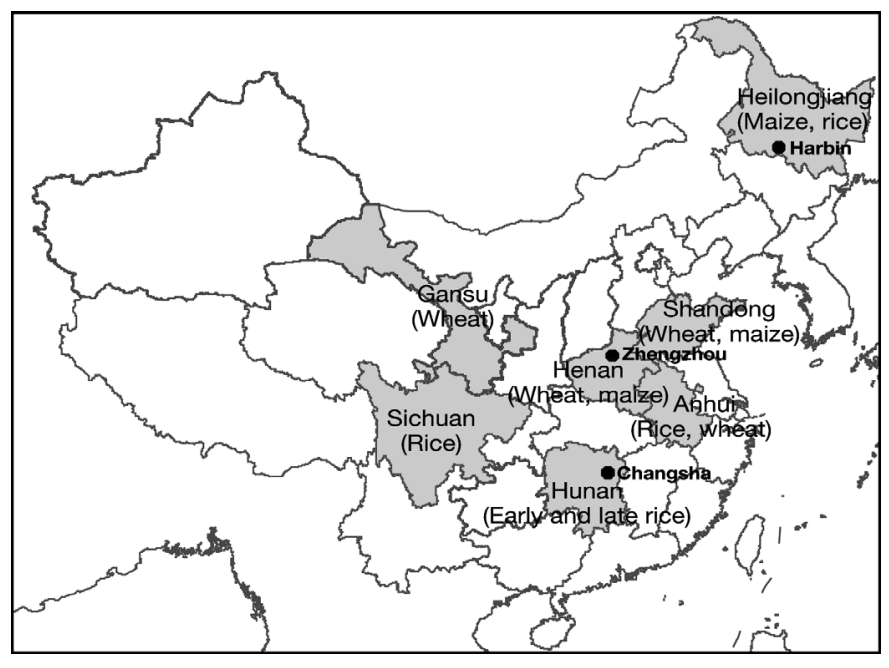

Fig. 1. Study areas in China and their main crops
Qian \& Lee 2000, Kripalani \& Kulkarni 2001, Qian et al. 2002, Yan 2002). The EAM has 2 distinct subsystems in the region from China to Japan, a winter and a summer (EASM) component (Lau 1992). The EASM has been investigated by many studies (e.g. Kao \& Hsu 1962, Lee 1974, Ninomiya \& Murakami 1987, Tao \& Chen 1987, Ding 1992, Matsumoto 1992). Nevertheless, the duration and spatial patterns of sub-seasonal climate variability, and the mechanisms leading to regional drought and flood disasters are not yet clear (Qian et al. 2002). The dependence of agricultural production variability on ENSO and its application to the forecasting of food production have been investigated in Africa, America, Europe, and South Asia (e.g. Cane et al. 1994, Jones et al. 2000, Orlove et al. 2000, Ferreyra et al. 2001, Gimeno et al. 2002, Mavromatis et al. 2002, Phillips et al. 2002, Meza \& Wilks 2003, Selvaraju 2003), but few such studies are available on EAM and ENSO in SE Asia or China. Our aims in this study were, to analyze for the major agricultural regions of China, (1) seasonal climate variability associated with EAM and ENSO and (2) the dependence of agricultural production on seasonal climate variability. The results are designed to help agricultural production cope with climate risks.

\section{METHODOLOGY AND DATA}

\subsection{Study area}

We investigated Chinese agricultural production at the national, Province and field scale. At the Province scale, 7 Provinces representing a variety of geographical and climatological conditions were selected as study areas (Fig. 1): Heilongjiang, Gansu, Shandong, Henan, Anhui, Sichuan, and Hunan. These are among the main agricultural production regions in China. At the field scale, 3 agricultural experiment stations were selected: Harbin in northern China, Zhengzhou in central China, and Changsha in southern China.

\subsection{Climate data}

Monthly data for temperature and precipitation from 1978 to 2000 at meteorological stations of the Provinces were obtained from the Chinese Meteorological Center. Temperature and precipitation data were spatially averaged on a monthly basis for each Province, and seasonal mean temperature and rainfall were computed for DJF, MAM, JJA and SON. We also examined seasonal mean daily minimum and maximum temperature, and seasonal mean monthly rainfall from 1981 to 2000 at the 3 agricultural experiment stations (Table 1). 
Table 1. Climate and agricultural data on China used in this study. $T$ : temperature $\left({ }^{\circ} \mathrm{C}\right)_{i}$ Prec: precipitation $(\mathrm{mm}) ;$ mo: monthly mean. Agricultural variables: food yield $\left(\mathrm{kg} \mathrm{ha}^{-1}\right)$ and production $\left(\times 10^{3} \mathrm{t}\right)$, total and food crop planting area $\left(\times 10^{6} \mathrm{ha}\right)$, cropland area (\%) affected and damaged by drought and flood disasters

\begin{tabular}{|lccc|}
\hline & National & Province & Agricultural station \\
\hline Datasets & 1 & 7 & 3 \\
Climate variables & - & $T_{\mathrm{mo}}, \mathrm{Prec}_{\mathrm{mo}}$ & $T_{\min }, T_{\max }, \mathrm{Prec}_{\mathrm{mo}}$ \\
Climate data & - & $1978-2000$ & $1980-2000$ \\
Rice, wheat and maize yield & $1961-2001$ & $1979-2000$ & $1981-2000$ \\
Other agricultural variables & $1961-2000$ & $1979-2000$ & - \\
\hline
\end{tabular}

surface temperature (SST) anomalies over the tropical Pacific: $4^{\circ} \mathrm{S}$ to $4^{\circ} \mathrm{N}$, and 150 to $90^{\circ} \mathrm{W}$. The ENSO year (October-September) is categorized as El Niño when the index values exceed $0.5^{\circ} \mathrm{C}$ for 6 consecutive months including October to December (OND), and as La Niña when index values are $<-0.5^{\circ} \mathrm{C}$ (Sittel 1994). The period 1979-2000 included 5 El Niño, 4 La Niña, and 13 neutral events (Table 2).

\subsection{EASM definitions}

EASM strength (strong, neutral, and weak) was classified according to the difference between the mean $u$ sub-vector of $850 \mathrm{hPa}$ from June to August over the areas 100 to $150^{\circ} \mathrm{E}, 10$ to $20^{\circ} \mathrm{N}$ (Region I) and 100 to $150^{\circ} \mathrm{E}, 25$ to $35^{\circ} \mathrm{N}$ (Region II). This index is defined in Zhang et al. (2000), based on the observation that when west-slanting atmosphere circulation occurs in the summer tropical monsoon trough region, the corresponding tropical monsoon trough will be relatively strong, and EASM will be weak with an east-slanting pattern. When the circulation of the atmosphere in the Meiyu front region in mid-latitude is east- (west-) slanting, the corresponding Meiyu front is relatively weak (strong) (Zhang \& Tao 1998). Each year is categorized as a strong monsoon year (index value $\geq 2$ ), a weak monsoon year (index value $\leq-2$ ), or neutral. The period 1979-1998 included 6 strong, 7 weak and 7 neutral years (Table 2).

\subsection{ENSO definitions}

The classification of ENSO phases was based on an index from the Japan Meteorological Agency. This index is a 5 mo running mean of spatially averaged sea

\subsection{Agricultural variables}

The dependence of crop growth and yield on seasonal climate variability associated with the EAM and ENSO is demonstrated by their correlation. To assess crop growth status we used the Normalized Difference Vegetation Index (NDVI) based on satellite data from the 'Twenty-year Global 4-minute AVHRR NDVI Dataset of Chiba University', processed from Pathfinder global $10 \mathrm{~d}$ composite $8 \mathrm{~km}$ AVHRR NDVI data (http://asiaserv.cr.chiba-u.ac.jp/ frame.htm). To avoid cloud effects, we used the maximum $10 \mathrm{~d}$ composite NDVI (i.e. the average NDVI during the $10 \mathrm{~d}$ with maximum Leaf Area Index, LAI) during the crop growing period. This procedure was conducted for each crop, based on the NDVI for cultivated land (grid cells with cultivated fraction $>0.20$ ).

The yield series of rice, wheat, and maize in China were extracted from the Food and Agricultural Organization (FAO) database (www.fao.org/ag/guides/ resource/data.htm). For each Province, the data on crop yield per planting area were obtained from the China Agriculture Annual Book (China Agriculture Publisher, Beijing). For the 3 meteorological stations, crop yield data from 1981 to 2000 were obtained from local agricultural experiment stations (Table 1).

Table 2. Classification of the East Asian summer monsoon (EASM; 1961-1998) and El Niño Southern Oscillation (ENSO; 1961-2001) by year, based on the NCAR/NCEP reanalysis data from Zhang et al. (2000)

\begin{tabular}{|lll|}
\hline & Classification $($ index; $\mathrm{n})$ & Year \\
\hline EASM & Strong $(\geq 2 ; 10)$ & $1967,1972,1974,1978,1981,1984,1985,1986,1994,1997$ \\
& Weak $(\leq-2 ; 10)$ & $1965,1969,1971,1980,1983,1988,1993,1995,1996,1998$ \\
& Neutral $(>-2$ to $<2 ; 18)$ & $1961,1962,1963,1964,1966,1968,1970,1973,1975,1976,1977,1979,1982,1987$, \\
& & $1989,1990,1991,1992$ \\
ENSO & El Niño $\left(>0.5^{\circ} C_{;} 10\right)$ & $1963,1965,1969,1972,1976,1982,1986,1987,1991,1997$ \\
& La Niña $\left(<-0.5^{\circ} \mathrm{C}_{;} 10\right)$ & $1964,1967,1970,1971,1973,1975,1988,1998,1999,2000$ \\
& Neutral $\left(-0.5\right.$ to $\left.0.5^{\circ} C_{;} 21\right)$ & $1961,1962,1966,1968,1974,1977,1978,1979,1980,1981,1983,1984,1985,1989$, \\
& & $1990,1992,1993,1994,1995,1996,2001$ \\
\hline
\end{tabular}




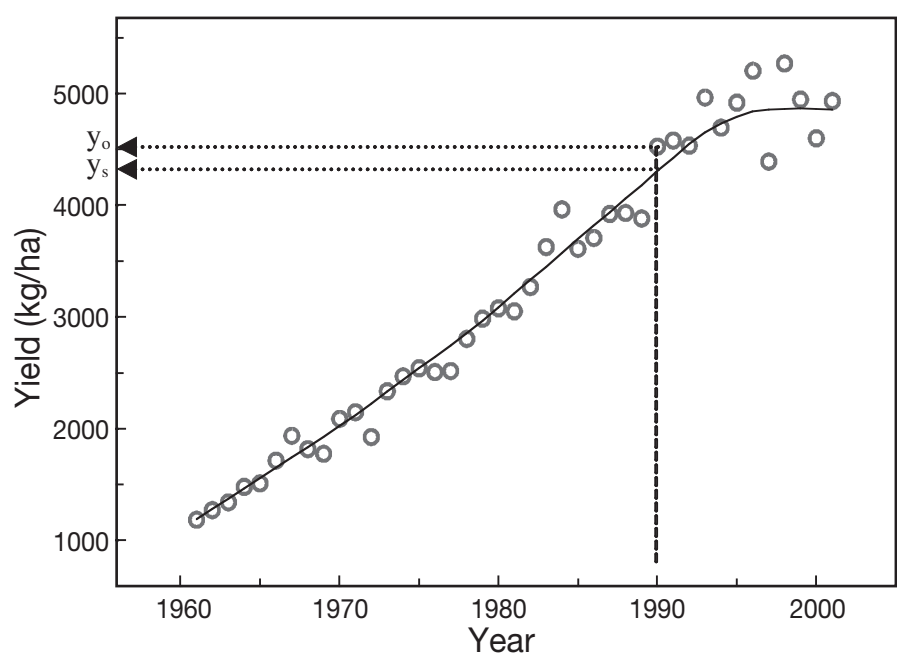

Fig. 2. Methodology used to analyze crop yield or production anomaly

The statistical data on crop planting area, agricultural production, and drought and flood disasters were from the China Agriculture Annual Book (Table 1).

\subsection{Analysis}

Hypothesized influences of EASM strength and ENSO phases on seasonal climate variability, crop yield and production anomalies, planting area, agricultural drought and flood disasters were tested by ANOVA.
For crop yield and production, high frequency anomalies attributed primarily to weather variability were separated from lower frequency trends attributed to changes in technology and management, by using Friedman's supersmoother (Friedman 1984), which applies a low-pass filter covering a specified period to detrended data. To avoid giving excessive weight to periods of high variability, the analysis was performed on the yield or production difference (in \%) between the observed $\left(y_{0}\right)$ and smoothed $\left(y_{\mathrm{s}}\right)$ to the smoothed $\left(y_{\mathrm{s}}\right)$ yield or production, i.e. $\left.\left[\left(y_{o}-y_{\mathrm{s}}\right) / y_{\mathrm{s}}\right] \times 100\right)($ Fig. 2).

The Tukey multiple comparison and $F$-test methods were used to identify which monsoon strength or ENSO phases differed significantly $(p<0.05)$ in their effects on crop and weather variables. We also used Pearson's correlation function to investigate the correlations among variability in crop growth (represented by NDVI), crop yield, and seasonal rainfall. Significance was tested by a 2-tailed $t$-test.

\section{RESULTS}

\subsection{Variability in climate and agricultural production associated with EASM}

\subsubsection{Seasonal climate}

Generally, strong EASM decreased fall temperature in Gansu and Sichuan Provinces, and winter temperature in Heilongjiang, Shandong and Anhui Provinces (Table 3). The fact that a strong EASM significantly

Table 3. Effect of East Asian summer monsoon (EASM) strength on seasonal climate and agricultural production in China for 1961-1998. Data are means (SD); means with different superscript letters among EASM classes are significantly different. Abbreviations and units as in Table 1 (except for maize yield, which is \%)

\begin{tabular}{|c|c|c|c|c|c|}
\hline \multirow[t]{2}{*}{ Parameter } & & \multirow[t]{2}{*}{ Location } & \multicolumn{3}{|c|}{ - EASM - } \\
\hline & & & Strong & Neutral & Weak \\
\hline \multirow[t]{6}{*}{$T_{\text {mean }}$} & Winter & Heilongjiang & $-18.49(0.82)^{b}$ & $-16.76(1.09)^{\mathrm{a}}$ & $-16.68(1.19)^{\mathrm{a}}$ \\
\hline & & Shandong & $-0.82(0.96)^{\mathrm{b}}$ & $0.41(0.42)^{\mathrm{a}}$ & $0.16(0.55)^{\mathrm{a}}$ \\
\hline & & Anhui & $3.16(0.87)^{\mathrm{b}}$ & $4.14(0.52)^{\mathrm{a}}$ & $3.92(0.53)^{\mathrm{ab}}$ \\
\hline & Fall & Gansu & $7.25(0.59)^{\mathrm{a}}$ & $7.86(0.65)^{\mathrm{ab}}$ & $8.35(0.78)^{b}$ \\
\hline & & Sichuan & $16.42(0.52)^{\mathrm{a}}$ & $16.96(0.45)^{\mathrm{ab}}$ & $17.35(0.77)^{\mathrm{b}}$ \\
\hline & & Hunan & $17.65(0.59)^{\mathrm{a}}$ & $18.25(0.45)^{\mathrm{ab}}$ & $18.71(0.79)^{b}$ \\
\hline$T_{\min }$ & Winter & Harbin & $-22.31(1.65)^{\mathrm{a}}$ & $-20.57(0.52)^{\mathrm{ab}}$ & $-19.52(1.38)^{b}$ \\
\hline$T_{\max }$ & Winter & Harbin & $-10.78(1.20)^{b}$ & $-8.51(1.01)^{\mathrm{a}}$ & $-8.19(1.14)^{\mathrm{a}}$ \\
\hline \multirow[t]{3}{*}{ Prec $_{m o}$} & Summer & Hunan & $136.4(39.4)^{\mathrm{a}}$ & $145.7(24.1)^{\mathrm{ab}}$ & $186.9(31.6)^{\mathrm{b}}$ \\
\hline & & Changsha & $132.1(48.3)^{a}$ & $137.2(29.5)^{\mathrm{a}}$ & $201.4(44.3)^{\mathrm{b}}$ \\
\hline & & Harbin & $161.0(33.4)^{\mathrm{b}}$ & $113.6(24.4)^{\mathrm{a}}$ & $114.4(22.5)^{\mathrm{a}}$ \\
\hline \multirow[t]{2}{*}{ Floods } & Cropland affected & Hunan & $7.39(5.61)^{\mathrm{a}}$ & $9.70(4.31)^{\mathrm{a}}$ & $20.96(7.38)^{\mathrm{b}}$ \\
\hline & Cropland damaged & Hunan & $4.29(4.53)^{\mathrm{a}}$ & $4.69(2.35)^{\mathrm{a}}$ & $13.23(5.33)^{\mathrm{b}}$ \\
\hline Maize yield & & Henan & $-8.69(13.02)^{\mathrm{a}}$ & $1.59(8.05)^{\mathrm{ab}}$ & $5.69(7.74)^{\mathrm{b}}$ \\
\hline
\end{tabular}


affected temperatures in fall and winter, but not in summer, should be studied further in relation to global climate circulation. Summer rainfall in Hunan Province and at some stations in NE China (e.g. Harbin) increased in weak EASM years.

The movement of the rain belt from south to north China strengthened in strong monsoon years, resulting in more rainfall in summer in NE China (e.g. $+47.4 \mathrm{~mm} \mathrm{mo}^{-1}$ in Harbin) in comparison with the neutral phase. In contrast, it weakened in weak monsoon years, resulting in a significant increase in rainfall in summer in southern China in comparison with the neutral phase (e.g. $41 \mathrm{~mm} \mathrm{mo}^{-1}$ in Hunan Province and $64 \mathrm{~mm} \mathrm{mo}^{-1}$ in Changsha; see Table 3).

\subsubsection{Agricultural production}

Among staple food crops in China, maize yield in Henan Province was the only crop whose yield was significantly influenced by EASM, increasing by about $14 \%$ in weak (compared to strong) monsoon years (Table 3). The main reason could be an increase in summer rainfall by $29.2 \mathrm{~mm} \mathrm{mo}^{-1}$, even if this increase is not significant. Increased precipitation in southern China in weak monsoon years also leads to significant increases in cropland area affected and damaged by flood disasters in Hunan Province (11.3 and 8.5\%, respectively) in comparison to those in neutral years (Table 3).

\subsection{Variability in climate and agricultural production associated with ENSO}

\subsubsection{Seasonal climate}

In comparison with EASM, which mainly influenced the precipitation variation in eastern China, the influences of ENSO extended to NW China. Mean temperature in summer of Heilongjiang and Gansu Provinces increased significantly by $>1^{\circ} \mathrm{C}$ during the La Niña phase in comparison with the neutral phase (Table 4). Rainfall in summer in Gansu Province decreased by about $20 \mathrm{~mm} \mathrm{mo}^{-1}$ during the El Niño phase. At the agricultural experiment stations, the minimum temperature in summer at Harbin increased by $1.79^{\circ} \mathrm{C}$ for the La Niña phase; the minimum temperature in spring at Zhengzhou increased by $1.16^{\circ} \mathrm{C}$ during the La Niña phase; and rainfall in summer at Changsha increased significantly by $87 \mathrm{~mm} \mathrm{mo}^{-1}$ for the La Niña phase in comparison with the neutral phase (Table 4).

\subsubsection{Agricultural production}

Maize yield was especially vulnerable to ENSO in comparison with rice and wheat. Maize yield on a national scale and specifically in Henan Province, one of the principal production areas, decreased significantly by 5 and $16 \%$, respectively, during the El Niño phase, in comparison to the neutral phase (Table 4). A decrease in rainfall (although not significant) in sum-

Table 4. Effect of El Niño Southern Oscillation (ENSO) phase on seasonal climate and agricultural production in China for 1961-2001. Data are means (SD); means with different superscript letters among EASM classes are significantly different. Abbreviations and units as in Table 1 (except for maize yield, which is \%)

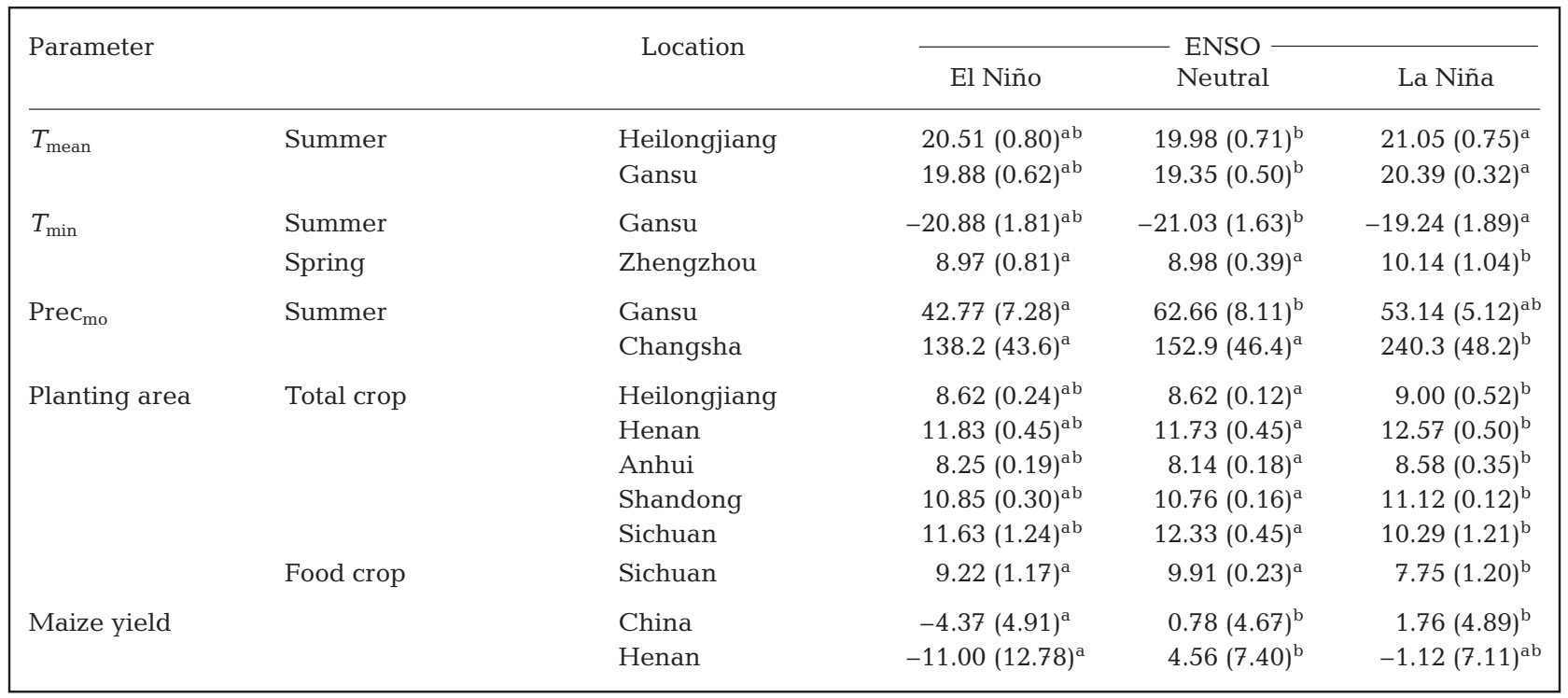



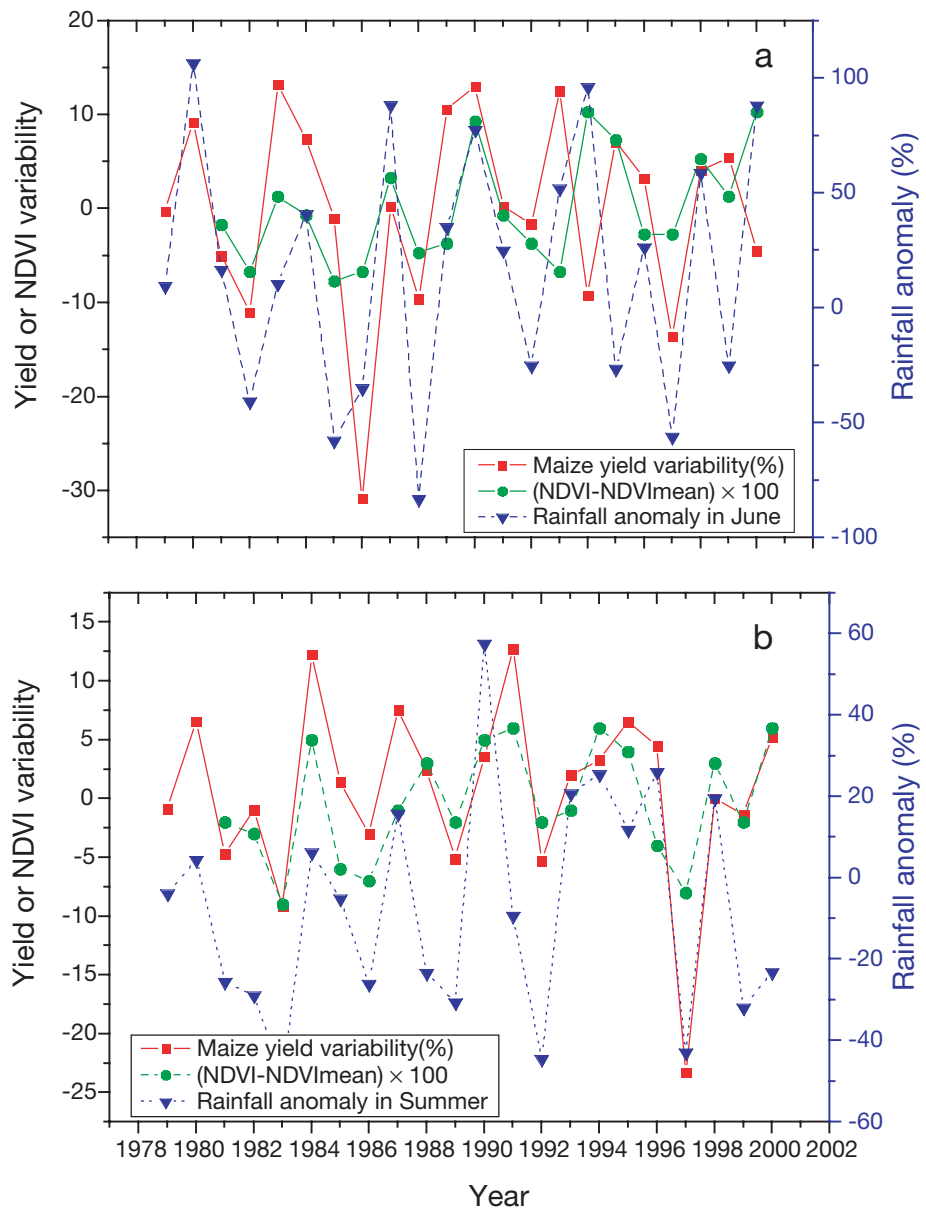

Fig. 3. Correlation among variability in crop growth (represented by Normalized Difference Vegetation Index [NDVI]), crop yield, and seasonal climate in (a) Henan and (b) Shandong Provinces

mer and fall could be the main reason for the maize yield decrease in Henan Province. During the La Niña phase, total crop planting areas increased significantly in Heilongjiang, Henan, Anhui and Shandong Provinces by about 400000 to 800000 ha in each Province. Increased temperature and/or precipitation in spring and/or summer could be the main reason. In contrast, total crop and food crop planting areas in Sichuan Province decreased significantly by 2 million ha during the La Niña phase (Table 4).

\subsection{Variability in seasonal climate and agricultural production}

There was a significant correlation among the mean maximum 10 d composite NDVI, maize yield variability, and seasonal rainfall variability in the north China plain (e.g. Shandong and Henan Provinces; Fig. 3). In Henan Province, the correlation coefficients between maize yield, NDVI and precipitation in June are 0.43 $(p<0.05)$ and $0.65(p<0.01)$, respectively. In Shandong Province, the correlation coefficients between maize yield, NDVI and precipitation in summer are 0.59 ( $\mathrm{p}<$ $0.01)$ and 0.53 ( $p<0.05)$, respectively. In strong EASM years such as 1985, 1986 and 1997 and in El Niño years such as 1982, 1986, and 1997, both rainfall and maize yield decreased in both Provinces. Fig. 3 also illustrates the combined effects of EASM and ENSO on agricultural production. For example, the maize yield in strong EASM and El Niño years, such as 1986 and 1997, was less than that in strong EASM non-El Niño years, such as 1985, or weak/neutral EASM and El Niño years, such as 1982.

\section{DISCUSSION}

\subsection{EASM, ENSO, seasonal climate variability, and agricultural production}

Seasonal precipitation associated with EASM and ENSO had a significant correlation with maize yield variability. Water availability is a major constraint for agriculture production in the arid, semi-arid, and semihumid regions of China (Tao et al. 2003). Crops during the summer monsoon period (June-September), e.g. maize, are subjected to seasonal rainfall variability associated with EASM and ENSO. Wheat growth and yield are typically sensitive to precipitation variability in spring (Bai et al. 1999) and paddy rice is typically sensitive to light and heat, but the seasonal climate variability associated with EASM and ENSO did not affect their yields significantly. We also found significant correlations between EASM and flood disasters in Hunan Province in southern China, as well between ENSO and the total crop planting area in some Provinces in central, NE and SW China. At the national scale, planting area, agricultural disasters, and total food production were, however, not significantly affected by either EASM or ENSO.

Some agricultural disasters associated with EASM or ENSO occurred in some years, yet not often enough to be statistically significant. Moreover, some effects were obscured by the following uncertainties: ENSO can be classified according to the intensity of SST anomaly, location and time of its beginning, and duration. Different types of ENSO could have different influences on regional climate variability. The Asian monsoon system is highly variable and may be coupled with ENSO or interact with some other component of global climate circulation (Huang et al. 1993, Charles et al. 1997, Kawamura 1998, Zahn 2003). Besides monsoon strength and ENSO phase, the evolution and extent of monsoons, and the strength, duration, season 
of occurrence, and development stage of ENSO also influence the regional seasonal climate (Qian \& Lee 2000). In addition, agricultural and meteorological statistics are collected according to administrative areas that are rarely homogeneous from an agricultural or agro-ecological (including climatic) point of view. Furthermore, the agricultural statistics represent an average of rain-fed and irrigated crops, and this can weaken the correlation between crop yield and seasonal climate variability.

\subsection{Food security early warning system based on EASM and ENSO forecasting}

It has been estimated that almost two-thirds (>500 million) of undernourished people live in the developing countries of Asia and the Pacific (FAO 1999). About 64 million undernourished people live in SE Asia, and more than 160 million live in China (FAO 1999). Moreover, in Asia, where agricultural input (e.g. fertilizer use, management effort) is high, farmers are approaching economically optimum yield levels, making it difficult to sustain the rate of yield gains attained in the past. Although efforts to improve long-term productivity on small farms must be increased, more emphasis must also be placed on research that will help farmers and the government cope with the expected increase in risks resulting from climate fluctuations, and to make better use of limited water resources (Jagtap \& Chan 2000).

Advances in seasonal climate forecasts offer considerable opportunities to improve yields (Jones et al. 2000, Hammer et al. 2001, Hansen 2002). Seasonal climate forecasts, including monthly rainfall, mean temperature, ENSO phase, and EASM strength (Song et al. 1996) could be made available to farmers in advance. The results of this study show there was quite a large production variability associated with EASM and ENSO. Moreover, EASM precipitation variability (Kitoh et al. 1997, Hu et al. 2000) and the frequency and strength of ENSO (Grove 1998) can be expected to increase by global warming. Therefore, a food security early warning system based on EASM and ENSO may improve planting and management decisions in China.

\section{CONCLUSION}

Seasonal climate variability and agricultural production in the principal agricultural production regions of China are affected by EASM and ENSO, and EASM and ENSO forecasts may imrove the management of agriculture and food markets.

The Asian monsoon system, ENSO, and their associations with regional seasonal climate variability are, however, complex, as are their implications for agricultural growth and production. Further studies should include longer time series of climate data, more detailed agricultural production records, detailed information on the monsoon system and ENSO, and the strength, duration, season of occurrence and development stage of ENSO. The combined effects of monsoons systems, ENSO and other components of global climate circulation must also be taken into account.

Acknowledgements. This study was supported by the International Global Change SysTem for Analysis, Research and Training (START) and the Eco-Frontier Fellowship in Japan. It was also partly funded by project no. 2004-BA611B-02 of the Chinese Ministry of Science and Technology. We thank START and Dr. James Hansen of the International Research Institute for Climate Prediction (IRI) for the 'advanced training institute on climate variability and food security', where we learned some of the methods used in the study. We are indebted to Ms. Amy Freise and Dr. Roland J. Fuchs of START for excellent coordination and management of the project. We also thank the anonymous reviewers and the editor for comments that improved the draft of this paper.

\section{LITERATURE CITED}

Bai Y, Li S, Huo Z (1999) Identification of the distribution of main agrometeorological disasters in China. In: Li S (ed) Risk assessment and strategies of agricultural disasters in china. Meteorological Press, Beijing, p 59-71

Cane MA, Eshel G, Buckland RW (1994) Forecasting Zimbabwean maize yield using eastern equatorial Pacific sea surface temperature. Nature 370:204-205

Charles CD, Hunter DE, Fairbanks RG (1997) Interaction between the ENSO and the Asian monsoon in a coral record of tropical climate. Science 277:925-928

Ding YH (1992) Summer monsoon rainfalls in China. J Meteorol Soc Jpn 70:373-396

FAO (1999) The state of food insecurity in the world 1999. Food and Agriculture Organization, Rome

Ferreyra RA, Podestá GP, Messina CD, Letson D, Dardanelli J, Guevara E, Meira S (2001) A linked-modeling framework to estimate maize production risk associated with ENSO-related climate variability in Argentina. Agric For Meteorol 107:177-192

Friedman JH (1984) A variable span scatterplot smoother. Tech Rep 5, Laboratory for Computational Statistics, Stanford University

Fu C, Teng X (1988) Relationship between ENSO and Chinese summer climate. Atmos Sci (Spec Issue):133-141 (in Chinese)

Fu C, Wen G (2001) Variation of ecosystems over East Asia in association with seasonal, interannual and decadal monsoon climate variability. Clim Change 43:477-494

Gimeno L, Ribera P, Iglesias R, Torre L, Garcia R, Hernandez $\mathrm{E}$ (2002) Identification of empirical relationships between indices of ENSO and NAO and agricultural yields in Spain. Clim Res 21:165-172

Gong D, Wang S (1999) Impacts of ENSO on rainfall of global land and China. Chin Sci Bull 44:852-857

Grove RH (1998) Global impact of the 1789-93 El Niño. Nature 393:318-319

Hammer GL, Hansen JW, Phillips JG, Mjelde JW, Hill H, Love 
A, Potgieter A (2001) Advances in application of climate prediction in agriculture. Agric Syst 70:515-553

Hansen JW (2002) Realizing the potential benefits of climate prediction to agriculture: issues, approaches, challenges. Agric Syst 74:309-330

Hansen JW, Jones JW, Kiker CF, Hodges AW (1999) El NiñoSouthern Oscillation impacts on winter vegetable production in Florida. J Clim 12:92-102

Hayashi Y (2001) Change of regional crop production under possible climate variation in East Asia. In: Proc Int Workshop, Crop Monitoring and Prediction at Regional Scales. 19-21 February 2001, Tsukuba, National Insitute of AgroEnvironmental Sciences, Science and Technology Agency of Japan, Tokyo, p 1-7

$\mathrm{Hu}$ ZZ, Latif M, Roeckner E, Bengtsson L (2000) Intensified Asian summer monsoon and its variability in a coupled model forced by increasing greenhouse gas concentrations. Geophys Res Lett 27:2681-2684

Huang R, Wu Y (1989) The influence of ENSO on the summer climate change in China and its mechanisms. Adv Atmos Sci 6:21-32

Huang R, Zhou LT (2002) Research on the characteristics, formation mechanism and prediction of severe climatic disasters in China. J Nat Disaster 11(1):1-9 (in Chinese)

Huang R, Yin B, Liu A (1993) Intraseasonal variability of the East Asian summer monsoon and its association with the convective activities in the tropical western Pacific. In: Ye D (ed) Climate variability. China Meteorological Press, Beijing, p 139-155

Jagtap SS, Chan AK (2000) Agrometeorological aspects of agriculture in the sub- humid and humid zones of Africa and Asia. Agric For Meteorol 103:59-72

Jones JW, Hansen JW, Royce FS, Messina CD (2000) Potential benefits of climate forecasting to agriculture. Agric Ecosyst Environ 82:169-184

Kane RP (1999) El Niño timings and rainfall extremes in India, Southeast Asia and China. Int J Climatol 19:653-672

Kao YH, Hsu SY (1962) Advance and retreat of East Asia monsoons and the beginning and ending of rainy periods. In: Kao YH (ed) Some problems on monsoons in East Asia. China Meteorological Press, Beijing, p 78-87 (in Chinese)

Kawamura R (1998) A possible mechanism of the Asian summer monsoon-ENSO coupling. J Meteorol Soc Jpn 76: 1009-1027

Kitoh A, Yukimoto S, Noda A, Motoi T (1997) Simulated changes in the Asian summer monsoon at times of increased atmospheric $\mathrm{CO}_{2}$. J Meteorol Soc Jpn 75: 1019-1031

Kripalani RH, Kulkarni A (1997) Rainfall variability over Southeast Asia - connections with Indian monsoon and ENSO extremes: new perspectives. Int J Climatol 17: 1155-1168

Kripalani RH, Kulkarni A (2001) Monsoon rainfall variations and teleconnections over South and East Asia. Int J Climatol 21:603-616

Lau KM (1992) East Asia summer monsoon rainfall variability and climate teleconnection. J Meteorol Soc Jpn 70: 211-241

Lee BS (1974) A synoptic study of early summer and autumn rainy season in Korea and in East Asia. Geogr Rep, Tokyo Meteorological University 9:79-96

Li S, Huo Z, Yang B (1999) Assessment of the effects of Chinese agricultural meteorological disasters on the Chinese economy. In: Li (ed) Risk assessment and strategies of agricultural disasters in China. China Meteorological Press, Beijing, p 96-99 (in Chinese)
Matsumoto J (1992) The seasonal changes in Asian and Australian monsoon regions. J Meteorol Soc Jpn 70: 257-273

Mavromatis T, Jagtap SS, Jones JW (2002) El Niño-Southern Oscillation effects on peanut yield and nitrogen leaching. Clim Res 22:129-140

Meza FJ, Wilks DS (2003) Value of operational forecasts of seasonal average sea surface temperature anomalies for selected rain-fed agricultural locations of Chile. Agric For Meteorol 116:137-158

Nicholson SE, Selato JC (2000) The influence of La Niña on African rainfall. Int J Climatol 20:1761-1776

Ninomiya K, Murakami T (1987) The early summer rainy season (Baiu) over Japan. In: Chang CP, Krishnamurti TN (eds) Monsoon meteorology. Oxford University Press, Oxford, p 60-92

Orlove BS, Chiang JCH, Cane MA (2000) Forecasting Andean rainfall and crop yield from the influence of El Niño on Pleiades visibility. Nature 403:68-71

Phillips JG, Deane D, Unganai L, Chimeli A (2002) Implications of farm-level response to seasonal climate forecasts for aggregate grain production in Zimbabwe. Agric Syst 74:351-369

Qian W, Lee D (2000) Seasonal march of Asian summer monsoon. Int J Climatol 20:1371-1386

Qian W, Kang HS, Lee DK (2002) Distribution of seasonal rainfall in the East Asian monsoon region. Theor Appl Climatol 73: 151-168

Selvaraju R (2003) Impact of El Niño-Southern Oscillation on Indian food grain production. Int J Climatol 23:187-206

Sittel MC (1994) Differences in the means of ENSO extremes for maximum temperature and precipitation in the United States. Tech Rep 94-2, Center for Ocean-Atmosphere Prediction Studies, Tallahassee

Song Y, Kau KM, Rao MS (1996) Precursory signals associated with the interannual variability of the Asia summer monsoon. J Clim 9:949-964

Tao F, Yokozawa M, Hayashi Y, Lin E (2003) Changes in agricultural water demands and soil moisture in China over the last half-century and their effects on agricultural production. Agric For Meteorol 118:251-261

Tao S, Chen L (1987) A review of recent research on the East Asia summer monsoon in China. In: Chang CP, Krishnamurti TN (eds) Monsoon meteorology. Oxford University Press, Oxford, p 60-92

Verschuren D, Laird KR, Cumming BF (2000) Rainfall and drought in equatorial east Africa during the past 1,100 years. Nature 403:410-414

Xu ZX, Takeuchi K, Ishidaira, H (2004) Correlation between El Niño-Southern Oscillation (ENSO) and precipitation in South-east Asia and the Pacific region. Hydrol Process 18:107-123

Yan Y (2002) Temporal and spatial patterns of seasonal precipitation variability in China. Phys Geogr 23:281-301

Zahn R (2003) Monsoon linkages. Nature 421:324-325

Zhang Q, Tao S (1998) Tropical and subtropical summer monsoons in East Asia and the precipitation in flood season in east China. Acta Appl Meteorol 9:16-23 (in Chinese)

Zhang Q, Cheng L, Tao S, Qiao Y (2000) Definition and prediction of East Asia monsoon index, and Asia atmosphere circulation. In: Study of comprehensive operation system on the monitoring, prediction and service of short-term climate. China Meteorology Press, Beijing, p 169-184 (in Chinese)

Zhang R, Sumi A, Kimoto K (1999) A diagnostic study of impact of El Niño on the precipitation in China. Adv Atmos Sci 16:229-241 